\title{
Hepatitis B virus antigens in primary hepatic carcinoma: immunofluorescent techniques on fixed liver tissue
}

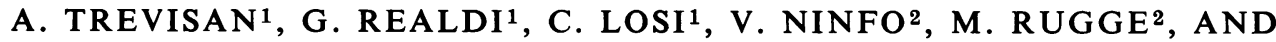 \\ L. RAMPINELLI3 \\ From the ${ }^{1}$ Istituto di Medicina Clinica, Cattedra di Patologia Medica dell'Università di Padova, \\ ${ }^{2}$ Istituto di Anatomia Patologicà dell'Università di Padova, and ${ }^{3}$ Servizio di Anatomia Patologica degli \\ Ospedali Civili Riuniti di Venezia, Italy
}

SUMMARY The presence of hepatitis B surface ( $\mathrm{HBs} \mathrm{Ag})$ and core $(\mathrm{HBcAg})$ antigens was investigated by immunofluorescence in specimens of liver tissue obtained at necrospy in 107 patients with primary hepatic carcinoma. HBsAg was detected in the cytoplasm of liver cells in 16 cases, and in eight of them the antigen was also found in malignant cells.

$\mathrm{HBcAg}$, which was present in the nuclei of liver cells in eight cases, was detected in the nuclei of tumour cells in six of these and also in two other cases showing HBsAg, but not HBcAg, in the nonneoplastic tissue. Although most of the primary hepatic carcinomas studied were associated with cirrhotic changes in the non-neoplastic tissue, HBsAg and HBcAg were also detected in the absence of underlying cirrhosis.

Hepatitis B virus markers were demonstrated in non-neoplastic tissue, mainly in patients with a well-differentiated carcinoma, and only in these cases were they found also in the neoplastic tissue.

These results show that hepatitis B virus antigens, including $\mathrm{HBcAg}$, can be detected in the neoplastic cells of well-differentiated carcinoma of the liver. Although these cells could have been infected after the malignant transformation, a direct oncogenic role of the virus cannot be excluded.

Serological markers of hepatitis B virus (HBV) infection (HBsAg, anti-HBs, anti-HBc) have been detected in patients with hepatocellular carcinoma, their incidence varying considerably in different geographical areas (Smith and Francis, 1972; Reed et al., 1973; Blumberg et al., 1975; Chainuvati et al., 1975; Maupas et al., 1975; Larouzé et al., 1976; Welsh et al., 1976; Kubo et al., 1977).

The HBsAg carrier state, with or without associated chronic liver disease, and hepatocellular carcinoma tend to occur in familial clusters in countries where both these conditions are common (Denison et al., 1971; Ohbayashi et al., 1972), suggesting a possible role of $\mathrm{HBV}$ in the aetiology of primary hepatic carcinoma. Direct evidence for HBV oncogenicity is, however, lacking.

The presence of $\mathrm{HBV}$ antigens ( $\mathrm{HBsAg}$ and $\mathrm{HBcAg}$ ) in the liver of chronic carriers of HBsAg has been extensively documented; in patients with HBV infection and primary hepatic carcinoma, HBsAg

Received for publication 15 May 1978 has been frequently detected in non-neoplastic liver cells, while the presence of HBV antigens in neoplastic tissue remains controversial (Portmann et al., 1976; Shikata, 1976). Nazarewicz et al. (1977) recently described HBsAg in the cytoplasm of cells of well-differentiated primary hepatic carcinoma; but $\mathrm{HBcAg}$ was not observed in neoplastic tissue by Hadziyannis et al. (1976).

In a retrospective study, we have now investigated by immunofluorescence the localisation of $\mathrm{HBsAg}$ and $\mathrm{HBcAg}$ in the livers of 107 cases of primary hepatic carcinoma.

\section{Material and methods}

A total of 107 necropsy cases of primary hepatic carcinoma (77 male and 30 female; age range 1-93 years) seen at the Istituto di Anatomia Patologica of the University of Padua and at the Servizio di Anatomia Patologica degli Ospedali Civili Riuniti in Venice from 1973 to 1977 were included in our study. 
Paraffin-embedded liver specimens were available from both neoplastic and non-neoplastic tissue, and serial sections were used for routine histological staining and immunofluorescent studies. Histological classification was based on the architectural structure of the tumour, according to Leevy and Tygstrup (1976). In addition, the tumours were graded according to their resemblance to original tissue, nuclear pleomorphism, and the number of mitoses, and were graded I to III, according to Hutt and Anthony (1973).

Seventeen patients with metastatic epithelial carcinoma of the liver were examined as controls.

\section{IMMUNOFLUORESCENCE OF LIVER TISSUE}

Paraffin sections, $5 \mu$ thick, were mounted on clean slides without adhesive. Deparaffinisation was accomplished by sequential passage through xylene and graded alcohols, and the sections were washed in phosphate-buffered saline (PBS) $\mathrm{pH} 7 \cdot 4$. These sections were then used for the identification of $\mathrm{HBcAg}$ and $\mathrm{HBsAg}$ by means of direct and indirect immunofluorescent techniques respectively. Serial sections were prepared from each block of liver.

\section{Indirect immunofluorescent techniques for HBs Ag}

The sections were incubated at $37^{\circ} \mathrm{C}$ for 45 minutes with rabbit anti-HBs (Behringwerke, Marburg) diluted 1:5, washed in PBS, and then treated for 30 minutes at $37^{\circ} \mathrm{C}$ with fluoresceinated goat antirabbit immunoglobulin (7s) (Meloy Lab. Dil. 1:8, F/P 4, Prot. C-12 mg/ml). The slides were then briefly rinsed in PBS and mounted in glycerol plus PBS. Immunofluorescent staining was examined with the Leitz Orthoplan Ploeomak fluorescence microscope. Control tests consisted of specific abolition of fluorescence by adsorption of the rabbit anti-HBs serum with a purified preparation of HBsAg containing a mixture of $a d$ and ay subtypes, prepared from plasma samples of healthy carriers according to Gerin et al. (1971).

\section{Direct immunofluorescent techniques for $\mathrm{HBcAg}$}

Anti-HBc human IgG was obtained from acute hepatitis B convalescent serum, which was anti-HBs negative by radioimmunoassay and anti-HBe negative by immunodiffusion. The IgG fraction was conjugated with fluorescein isothyocyanate (FITC), according to Arnold and Mayersbach (1972), and used at a final concentration of $0.5 \mathrm{mg}$ protein $/ \mathrm{ml}$. This serum showed a strong nuclear fluorescence when tested on reference liver tissue rich in $\mathrm{HBcAg}$.

Deparaffinised sections were incubated at $37^{\circ} \mathrm{C}$ for 30 minutes with the conjugated serum. Fluorescence was considered specific when blocked by unlabelled antiserum in the inhibition test. Moreover, positive results were confirmed with two reference anti-HBc FITC-labelled sera. All the sections with a positive reaction for $\mathrm{HBsAg}$ and/or $\mathrm{HBcAg}$ were then washed in PBS, stained with haematoxylin and eosin, and permanently mounted. Photographs were taken using Kodak Ektachrome daylight 200 ASA film before and after this last procedure.

\section{Results}

Histological CLASSIFICATION (Table 1)

Thirty-six patients had a well-differentiated carcinoma grade I, 37 a moderately well-differentiated carcinoma grade II, while a poorly differentiated carcinoma grade III was present in 34 cases.

The trabecular and/or pseudoglandular patterns were observed most frequently in the grades I and II

Table 1 Histological classification of primary hepatic carcinoma and underlying liver pathology

\begin{tabular}{|c|c|c|c|c|c|c|c|}
\hline \multirow[t]{2}{*}{ No. of cases } & \multirow[t]{2}{*}{ Sex } & \multirow{2}{*}{$\begin{array}{l}\text { Age (mean range) } \\
\text { (years) }\end{array}$} & \multicolumn{2}{|c|}{ Histological classification } & \multicolumn{3}{|c|}{ Underlying liver pathology } \\
\hline & & & Grade & Morphology & $N S R H$ & $C A H$ & Cirrhosis \\
\hline 34 & $13 \mathrm{~F}$ & $63(19-79)$ & $\begin{array}{l}\text { III } \\
\text { Poorly } \\
\text { differentiated }\end{array}$ & $\begin{array}{l}\text { Trabecular } \\
\text { Pseudoglandular } \\
\text { Solid } \\
\text { Pleomorphic }\end{array}$ & $\begin{array}{l}0 \\
1 \\
0 \\
5\end{array}$ & $\begin{array}{l}0 \\
\emptyset \\
\emptyset \\
2\end{array}$ & $\begin{array}{l}1(1)^{*} \\
3 \\
2 \\
20(2)^{*}\end{array}$ \\
\hline
\end{tabular}

NSRH = non-specific reactive hepatitis; CAH $=$ chronic active hepatitis.

* Numbers of cases with cirrhosis and associated chronic active hepatitis are given in parentheses. 
Table 2 Relationship between histological pattern of primary hepatic carcinoma, underlying liver disease, and HBsAg and HBcAg localisation in non-neoplastic and neoplastic liver

\begin{tabular}{|c|c|c|c|c|c|c|c|}
\hline \multirow{2}{*}{$\begin{array}{l}\text { Patient } \\
\text { Sex/Age }\end{array}$} & \multicolumn{2}{|c|}{ Histological pattern of $P H C$} & \multirow{2}{*}{$\begin{array}{l}\text { Underlying liver } \\
\text { disease }\end{array}$} & \multicolumn{2}{|c|}{ HBsAg localisation } & \multicolumn{2}{|c|}{ HBcAg localisation } \\
\hline & Grade & $\begin{array}{l}\text { Cytoarchitectural } \\
\text { structure }\end{array}$ & & $\begin{array}{l}\text { Non-neoplastic } \\
\text { tissue }\end{array}$ & $\begin{array}{l}\text { Neoplastic } \\
\text { tissue }\end{array}$ & $\begin{array}{l}\text { Non-neoplastic } \\
\text { tissue }\end{array}$ & $\begin{array}{l}\text { Neoplastic } \\
\text { tissue }\end{array}$ \\
\hline 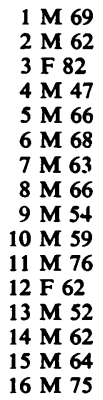 & $\begin{array}{l}\text { I } \\
\text { I } \\
\text { I } \\
\text { I } \\
\text { I } \\
\text { I } \\
\text { II } \\
\text { III } \\
\text { I } \\
\text { I } \\
\text { II } \\
\text { I } \\
\text { I } \\
\text { I } \\
\text { I } \\
\text { I }\end{array}$ & $\begin{array}{l}\text { Trabecular } \\
\text { Trabecular } \\
\text { Pseudoglandular } \\
\text { Trabecular } \\
\text { Clear cells } \\
\text { Trabecular } \\
\text { Pseudoglandular } \\
\text { Pleomorphic } \\
\text { Pseudoglandular } \\
\text { Trabecular } \\
\text { Pseudoglandular } \\
\text { Pseudoglandular } \\
\text { Trabecular } \\
\text { Trabecular } \\
\text { Trabecular } \\
\text { Trabecular }\end{array}$ & $\begin{array}{l}\text { Cirrhosis } \\
\text { Cirrhosis } \\
\text { Cirrhosis } \\
\text { Cirrhosis } \\
\text { Cirrhosis } \\
\text { Cirrhosis } \\
\text { Cirrhosis } \\
\text { Cirrhosis } \\
\text { CAH + cirrh } \\
\text { CAH + cirrh } \\
\text { CAH + cirrh } \\
\text { CAH } \\
\text { CAH } \\
\text { CAH } \\
\text { NSRH } \\
\text { NSRH }\end{array}$ & $\begin{array}{l}++ \\
++ \\
++ \\
+++ \\
++ \\
++ \\
++ \\
++ \\
++ \\
+++ \\
++ \\
++ \\
++ \\
++ \\
+++ \\
+++\end{array}$ & $\begin{array}{l}\text { Negative } \\
+ \\
+ \\
+++ \\
\text { Negative } \\
\text { Negative } \\
\text { Negative } \\
\text { Negative } \\
+ \\
+ \\
\text { Negative } \\
+ \\
++ \\
\text { Negative } \\
+ \\
\text { Negative }\end{array}$ & $\begin{array}{l}+ \\
\text { Negative } \\
\text { Negative } \\
+ \\
\text { Negative } \\
\text { Negative } \\
\text { Negative } \\
+ \\
+ \\
\text { Negative } \\
+ \\
\text { Negative } \\
+ \\
++ \\
\text { Negative } \\
+\end{array}$ & $\begin{array}{l}+ \\
\text { Negative } \\
\text { Negative } \\
+ \\
+++ \\
+++ \\
\text { Negative } \\
\text { Negative } \\
+ \\
\text { Negative } \\
\text { Negative } \\
\text { Negative } \\
++ \\
+++ \\
\text { Negative } \\
+\end{array}$ \\
\hline
\end{tabular}

$\mathrm{CAH}=$ chronic active hepatitis; NSRH $=$ non-specific reactive hepatitis

+++ several cells; ++ few cells $:+$ rare cells.

tumours, while the pleomorphic pattern was predominant in the poorly differentiated tumours. An underlying cirrhosis was present in 85 cases, and chronic active hepatitis was seen in eight. Features ascribed to only non-specific reactive hepatitis were observed in 13 cases.

DETECTION OF HBSAg BY IMMUNO-

FLUORESCENCE (Table 2)

HBsAg was detected in the non-neoplastic tissue of
$16(14.9 \%)$ of the 107 cases of hepatocellular carcinoma (13 grade I, 2 grade II, 1 grade III). Cirrhosis was present in 11 of these 16 cases, and the remaining five showed underlying chronic active hepatitis ( 3 cases) or non-specific reactive hepatitis ( 2 cases).

HBsAg positive cells were scattered among cases with chronic active hepatitis or cirrhosis, while a sheet distribution was found in cases of non-specific reactive hepatitis. $\mathrm{HBsAg}$ was also present in the

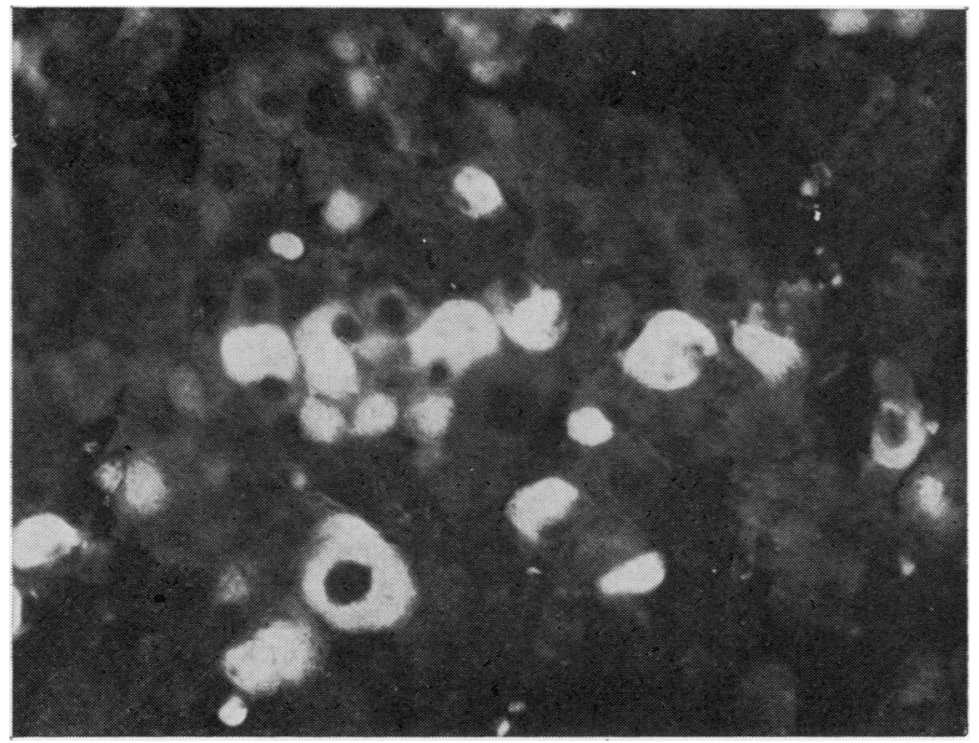

Fig. 1 Hepatitis $B$ surface antigen in cells of well-differentiated hepatocellular carcinoma (indirect immunofluorescence $\times 400$ ). 


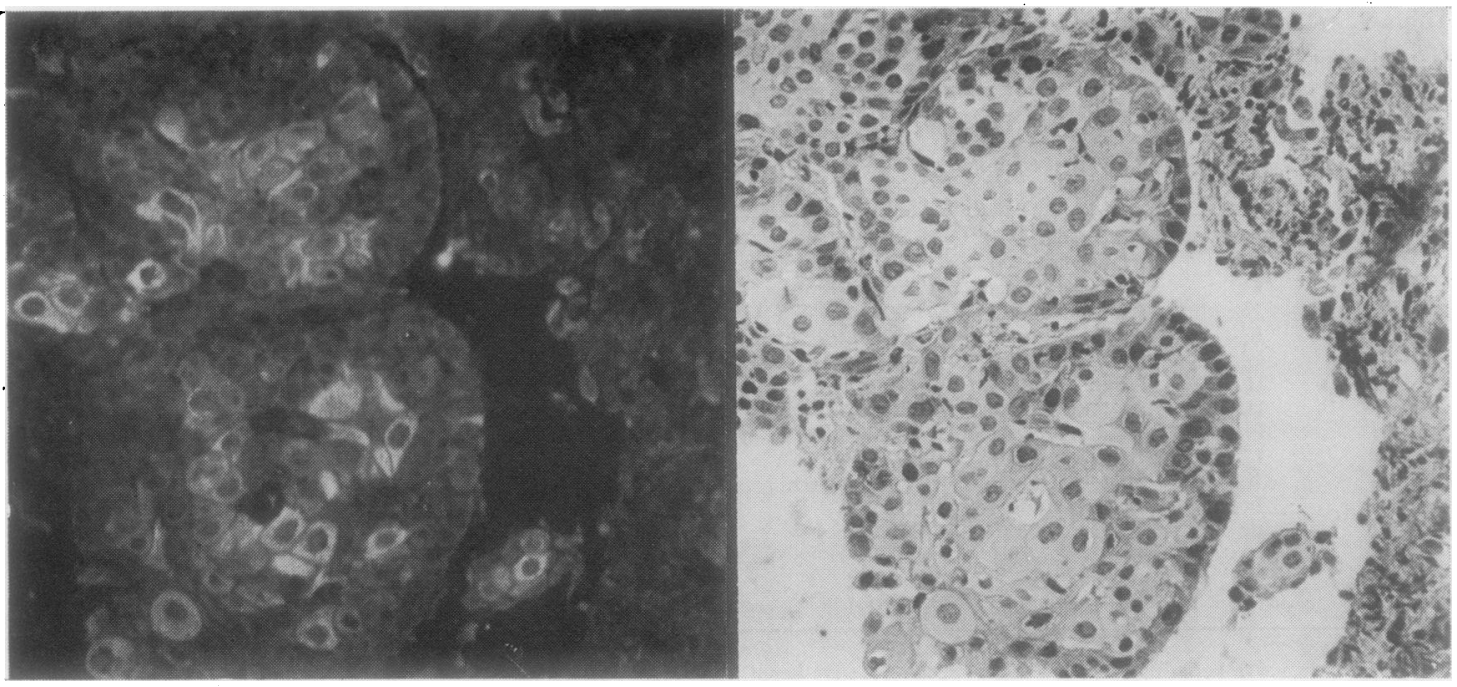

Fig. 2 (a) Cytoplasmic localisation of HBsAg in a large number of cells from well-differentiated primary hepatic carcinoma; (b) the same field stained by haematoxylin and eosin $(\times 280)$.

cytoplasm of cancer cells in eight cases (all grade I). The number of HBsAg containing cells was lower in the neoplastic tissue compared to the normal tissue. Many positive neoplastic cells were arranged in clusters in one case (No. 4) (Fig. 1), while in the others, cells containing HBsAg were rare and were located at the periphery of the neoplastic tissue. After haematoxylin and eosin staining these cells were considered to be part of the carcinoma (Fig. 2). The brightness of the HBsAg positive cells in malignant tissue was uniformly weaker in comparison with the positively stained hepatocytes in the nonneoplastic area.

HBsAg specific fluorescence was never observed in connective tissue, bile ducts, proliferating ductular cells or vessels. Small dense round deposits of $\mathrm{HBsAg}$ positive material were occasionally detected in necrotic areas.

Immunofluorescent specificity was confirmed by blocking tests with HBsAg, prepared as previously described. FITC goat anti-rabbit immunoglobulins completely lost their staining ability on positive liver tissue when the first incubation was carried out with anti-HBs serum mixed with purified HBsAg.

DETECTION OF HBCAg BY IMMUNO-

FLUORESCENCE

$\mathrm{HBcAg}$ in a granular pattern was detected in the nuclei of non-neoplastic cells in eight cases $(6$ grade I; 1 grade II; 1 grade III) with a focal distribution of positive hepatocytes. In six of these cases $\mathrm{HBcAg}$ was also found in scattered nuclei in the neoplastic cells (Fig. 3). In two other cases, which were negative for $\mathrm{HBcAg}$ in non-neoplastic tissue, many cancer cells showed a positive nuclear reaction with anti$\mathrm{HBc}$ serum (Fig. 4). The nuclear pattern of $\mathrm{HBcAg}$ in neoplastic tissue was similar to that observed in normal cells.

All positive results could be inhibited by unlabelled anti-HBc serum and were confirmed when reference anti-HBc sera were used.

Neither HBsAg nor $\mathrm{HBcAg}$ was detected in any of the metastatic epithelial carcinomas of the liver studied.

\section{Discussion}

This study represents, to our knowledge, the largest series yet reported of cases with primary hepatic carcinoma investigated for the presence of hepatitis B virus markers in the liver (Hadziyannis et al., 1976; Portmann et al., 1976; Shikata, 1976; Nazarewicz et al., 1977).

Serum was not available in most cases, this study being retrospective, and therefore it was difficult to establish the exact incidence of HBV infection in our patients. It is likely that the subjects positive in the liver $(15 \%)$ represent only those with a more active rate of virus replication.

We detected HBsAg in both neoplastic and nonneoplastic tissue not only in primary hepatic carcinoma with underlying cirrhosis but also in association with chronic active hepatitis or nonspecific reactive hepatitis. The expression of surface 


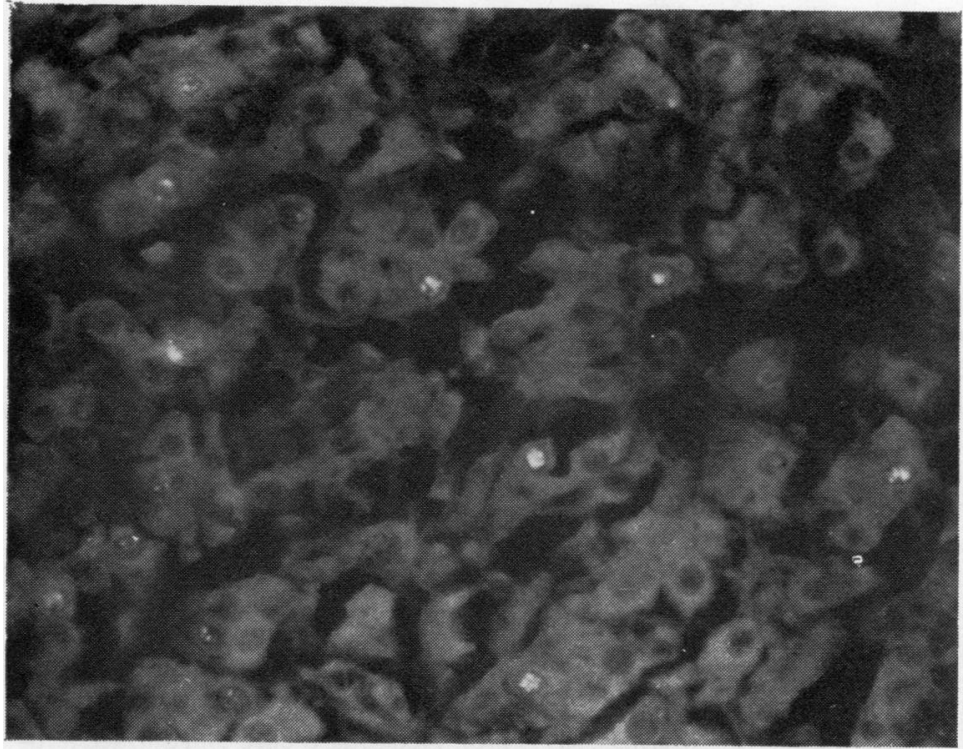

Fig. 3 Staining of intranuclear $\mathrm{HBCAg}$ in well-differentiated tumour cells (direct immunofluorescence $\times 260)$.

and core antigens in non-neoplastic tissue often recalled the distribution pattern seen in chronic carriers of HBV infection (Gudat et al., 1975). In primary hepatic carcinoma with underlying nonspecific reactive hepatitis, many $\mathrm{HBsAg}$ positive cells were arranged in sheets while $\mathrm{HBcAg}$ was poorly represented; $\mathrm{HBsAg}$ positive hepatocytes were irregularly scattered throughout the lobules or arranged in a nodular form, with a variable number of positive nuclei for $\mathrm{HBcAg}$ in the cases with underlying cirrhosis or chronic active hepatitis.

$\mathrm{HBsAg}$ and $\mathrm{HBcAg}$ were distributed more irregu- larly in the malignant areas than in non-neoplastic tissue. This difference in viral expression may reflect different metabolic properties of the neoplastic cells. Tumour cells contained different amounts of viral antigens, and virus proliferation usually occurred in the peripheral neoplastic cells rather than in the central tumour areas. These findings suggest that virus infection in neoplastic cells may be an expression of variable metabolic environment within uniform cell clones. Cytochemical properties different from those of normal hepatocytes could determine differences in virus infection and replication,

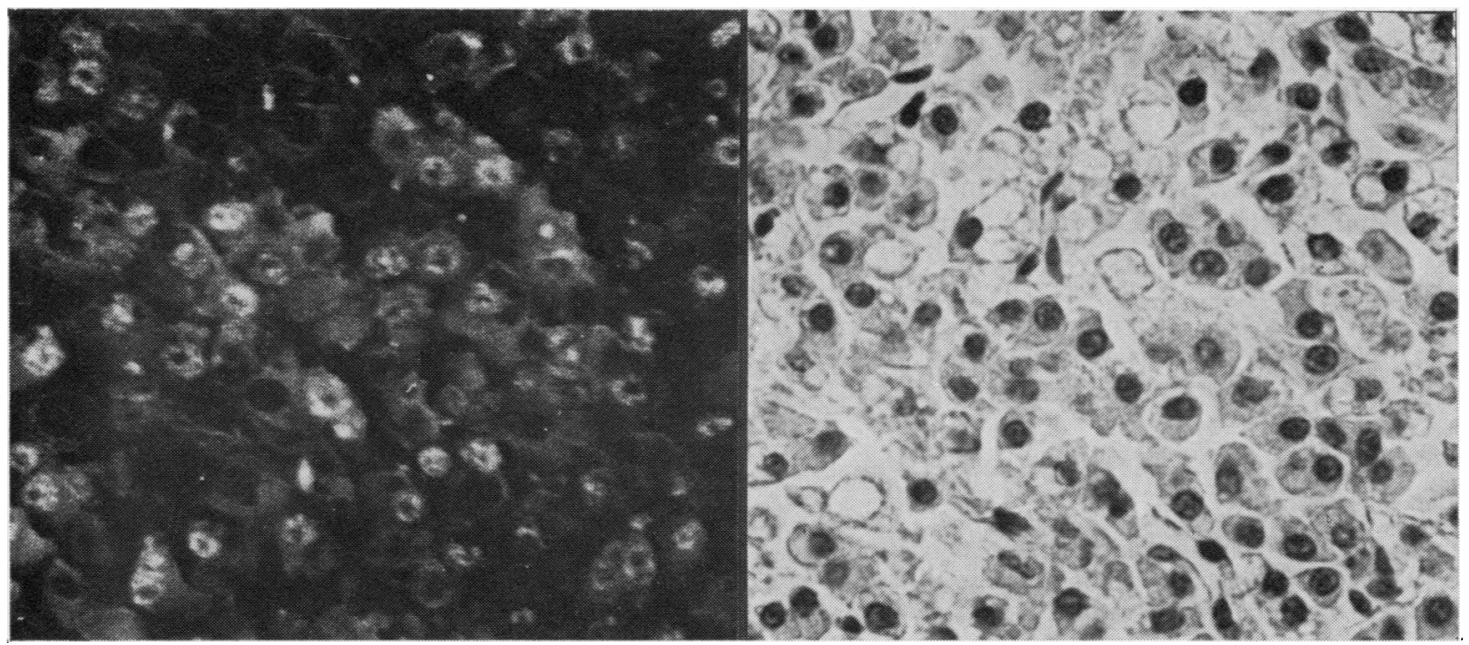

Fig. 4 (a) Nuclear localisation of $\mathrm{HBcAg}$ in a well-differentiated primary hepatic carcinoma, using an FITC-labelled anti-HBc; (b) the same field stained by haematoxylin and eosin $(\times 480)$. 
since the number of susceptible cells and their accessibility to a virus are related to their cooperation with its replicative cycle (Smith and Francis, 1972).

HBV markers were detected mainly in the liver of patients with a well-differentiated tumour, and in all these cases either $\mathrm{HBsAg}$ or $\mathrm{HBcAg}$ or both were found also in malignant cells.

The association we found between HBV infection and well-differentiated primary hepatic carcinoma is a surprising finding, and its interpretation is difficult. However, HBsAg was also detected in the liver of three patients with less well-differentiated tumour, andit was interesting to note that in these cases HBV antigens were never observed in the malignant cells. These observations suggest that HBV replicates in well-differentiated neoplastic cells, in agreement with the findings of Nazarewicz et al. (1977). We have now described the presence of $\mathrm{HBcAg}$, which is related more to HBV replication than is $\mathrm{HBs} A \mathrm{Ag}$, in these cells. This is in agreement with the results of Watanabe et al. (1976), who found an active replication and proliferation of HBV in 'oval cell' (immature hepatocyte) cultures.

The higher susceptibility to HBV infection of welldifferentiated primary hepatic carcinoma cells, as compared to poorly differentiated tumours, could support the hypothesis that highly differentiated hepatoma cells, showing minimal deviation from normal (Glazer et al., 1974), are as susceptible as hepatocytes to HBV growth.

Our results revive the question whether virus has a direct oncogenic role in primary hepatic carcinoma associated with HBV infection. Moreover, the absence of an underlying cirrhosis in five cases of hepatocellular carcinoma suggests that the association with HBV infection cannot be explained simply by the occurrence of malignant changes in the cirrhotic nodules.

We thank Dr Krawzynski, Warsaw, and Dr Rizzetto, Turin, who kindly provided reference anti-HBc sera. We also thank Miss Antonella Trivellato for editorial assistance

This work was supported in part by a grant (no. 76 . 01843. 04) from Consiglio Nazionale delle Ricerche, Rome, Italy.

\section{References}

Arnold, W., and Mayersbach, H. Von (1972). Changes in the solubility of immunoglobulins after fluorescent labeling and its influence on immunofluorescent techniques. Journal of Histochemistry and Cytochemistry, 20, 975985.

Blumberg, B. S., Larouzé, B., London, W. T., Werner, B., Hesser, J. E., Millman, I., Saimot, G., and Payet, M.
(1975). The relation of infection with the hepatitis B agent to primary hepatic carcinoma. American Journal of Pathology, 81, 669-682.

Chainuvati, T., Viranuvatti, V., and Pongpipat, D. (1975). Relationship of hepatitis B antigen in cirrhosis and hếpatoma in Thailand. Gastroenterology, 68, 1261-1264.

Denison, E. K., Peters, R. L., and Reynolds, T. B. (1971). Familial hepatoma with hepatitis-associated antigen. Annals of Internal Medicine, 74, 391-394.

Gerin, J. L., Holland, P. V., and Purcell, R. H. (1971). Australia antigen: large-scale purification from human serum and biochemical studies of its proteins. Journal of Virology, 7, 569-576.

Glazer, R. I., Vogel, C. L., Patel, I. R., and Anthony, P. P. (1974). Glutamate dehydrogenase activity related to histopathological grade of hepatocellular carcinoma in man. Cancer Research, 34, 2975-2978.

Gudat, F., Bianchi, L., Sonnabend, W., Thiel, G., Aenishaenslin, W., and Stalder, G. A. (1975). Pattern of core and surface expression in liver tissue reflects state of specific immune response in hepatitis B. Laboratory Investigation, 32, 1-9.

Hadziyannis, S. J., Giustozi, A., Moussouros, A., and Merikas, G. (1976). Hepatitis B core and surface antigens in the liver in primary liver cell carcinoma. In Diseases of the Liver and Biliary Tract, edited by C. M. Leevy, pp. 174-178. Karger, Basle.

Hutt, M. S. R., and Anthony, P. P. (1973). Tumours of liver, biliary system and pancreas. Recent Results in Cancer Research, 41, 57-78.

Kubo, Y., Okuda, K., Shimokawa, Y., Arishima, T. Nagata, E., Hashimoto, M., Jinnouchi, S., Sawa, Y. Obata, H., and Hayashi, N. (1977). Hepatitis B surface antigenemia in patients with hepatocellular carcinoma in relation to clinical course and alphafetoprotein. Gastroenterology, 72, 1213-1216.

Larouzé, B., London, W. T., Saimot, G., Werner, B. G., Lustbader, E. D., Payet, M., and Blumberg, B. S. (1976). Host responses to hepatitis-B infection in patients with primary hepatic carcinoma and their families. Lancet, 2, 534-538.

Leevy, C. M., and Tygstrup, N. (1976). Standardisation of nomenclature, diagnostic criteria and diagnostic methodology for diseases of the liver and biliary tract. In Diseases of the Liver and Biliary Tract, edited by C. M. Leevy (Appendix), pp. 44-49. Karger, Basle.

Maupas, P., Werner, B., Larouzé, B., Millman, I., London, W. T., O'Connell, A., Blumberg, B. S., Saimot, G., and Payet, M. (1975). Antibody to hepatitis-B core antigen in patients with primary hepatic carcinoma. Lancet, 2, 9-11.

Nazarewicz, T., Krawzyński, K., Ślusarczyk, J., and Nowoslawski, A. (1977). Cellular localisation of hepatitis B virus antigens in patients with hepatocellular carcinoma coexisting with liver cirrhosis. Journal of Infectious Diseases, 135, 298-302.

Ohbayashi, A., Okochi, K., and Mayumi, M. (1972). Familial clustering of asymptomatic carriers of Australia antigen and patients with chronic liver disease or primary liver cancer. Gastroenterology, 62, 618-625.

Portmann, B., Galbraith, R. M., Eddleston, A. L. W. F., 
Zuckerman, A. J., and Williams, R. (1976). Detection of $\mathrm{HBsAg}$ in fixed liver tissue. Use of a modified immunofluorescent technique and comparison with histochemical methods. Gut, 17, 1-9.

Reed, W. D., Eddleston, A. L. W. F., Stern, R. B., Williams, R., Zuckerman, A. J., Bowes, A., and Earl, P. M. (1973). Detection of hepatitis B antigen by radioimmunoassay in chronic liver disease and hepatocellular carcinoma in Great Britain. Lancet, 2, 690-694.

Shikata, T. (1976). Histological and electron-microscopical observation of $\mathrm{HB}$ antigen in hepatitis, liver cirrhosis and hepatocellular carcinoma. In Diseases of the Liver and Biliary Tract, edited by C. M. Leevy, pp. 170-173. Karger, Basle.

Smith, J. A., and Francis, T. I. (1972). Immunoepidemiological and in vitro studies of possible relationships between Australia antigen and hepatocellular carcinoma. Cancer Research, 32, 1713-1720.

Watanabe, M., Umenai, T., Ohori, H., and Ishida, N. (1976). Evidence for the multiplication of hepatitis $B$ virus in "oval cell" culture originated from human embryonic liver. British Journal of Experimental Pathology, 57, 211-216.

Welsh, J. D., Brown, J. D., Arnold, K., Mathews, H. M., and Prince, A. M. (1976). Hepatitis Bs antigen, malaria titers, and primary liver cancer in South Vietnam. Gastroenterology, 70, 392-396.

Requests for reprints to: Dr G. Realdi, Istituto di Medicina Clinica, Centro di Splenoepatologia, Via Giustiniani 2, 35100 Padova, Italy. 